\title{
Clinical Reasoning: A 25-year-old woman with recurrent episodes of collapse and loss of consciousness
}

Jack Wildman, MBBS, Mark R. Baker, PhD, FRCP, D. Ashley Price, MD, FRCP, Sarbesh Tiwari, MD, Hrishikesh Kumar, MD, Gillian I. Rice, PhD, Yanick J. Crow, PhD, MRCP, and Rhys H. Thomas, PhD, FRCP

Neurology ${ }^{\circledR}$ 2020;94:994-999. doi:10.1212/WNL.0000000000009533

\author{
Correspondence \\ Dr. Thomas \\ rhys.thomas@ncl.ac.uk
}

\section{Section 1}

A 25-year-old woman presented to the neurology clinic describing 3 episodes of transient loss of consciousness over 9 months. The first 2 were unwitnessed, with no prodromal symptoms. The third event was a witnessed collapse while shopping. It was reported that both the patient's arms were stiff and by her sides with accompanied lateral tongue biting, a blue discoloration to her face, choking noises, and dilated pupils. The event lasted for less than 2 minutes, after which she was confused and drowsy. She remembered a premonitory feeling before the third collapse but found this difficult to describe.

The patient's medical history included migraine and mild depression; she took amitriptyline $20 \mathrm{mg}$ daily and citalopram $20 \mathrm{mg}$ daily. She had been born at 26 weeks' gestation but had no medical complaints or adverse early-life events, had normal developmental milestones, and was a university student. There was no family history of note. On direct questioning she described symptoms of infrequent but potent déjà-vu as well as general fatigue and lack of focus. She smoked 8-10 cigarettes per day and drank a small amount of alcohol on social occasions. She had a balanced diet and was a meat-eater.

On examination, power and sensation were normal throughout. Bilateral optic disc swelling was seen on funduscopy; the remainder of the cranial nerve examination was normal. The patient had globally brisk reflexes, more prominent on the right (left $3+$, right $4+$ ). She had increased tone in her lower limbs, right greater than left, but plantar responses were downgoing. Cardiorespiratory and abdominal examination was normal and she had no neurocutaneous markers.

\section{Questions for consideration:}

1. What is the differential diagnosis for these events?

2. What investigations would you consider?

\section{GO TO SECTION 2}

\footnotetext{
From the Departments of Neurology (J.W., M.R.B., R.H.T.), Clinical Neurophysiology (M.R.B.), and Infectious Disease (D.A.P.), Royal Victoria Infirmary; Institute of Neuroscience (M.R.B., R.H.T.), Newcastle-Upon-Tyne, UK; Institute of Neurosciences Kolkata (S.T., H.K.), India; Division of Evolution and Genomic Sciences (G.I.R.), School of Biological Sciences, Faculty of Biology, Medicine and Health, University of Manchester, Manchester Academic Health Science Centre; Centre for Genomic and Experimental Medicine (Y.C.), MRC Institute of Genetics and Molecular Medicine, University of Edinburgh, UK; and Laboratory of Neurogenetics and Neuroinflammation (Y.C.), Institut Imagine, Paris Descartes University, France.

Go to Neurology.org/N for full disclosures. Funding information and disclosures deemed relevant by the authors, if any, are provided at the end of the article.
} 


\section{Section 2}

The differential for unwitnessed collapse and loss of consciousness ranges from the common such as epileptic or provoked seizures, syncope, and dissociative attacks to rarities including insulinoma or colloid cyst of the fourth ventricle. The most common differentials for episodes of loss of consciousness are seizures, both spontaneous and provoked; reflex vasovagal syncope; and cardiac syncope. Thus ECG is essential in all cases of transient loss of consciousness. Recurring events narrow the differential by facilitating identification of triggers or sequences of events and increasing the likelihood of an event being witnessed. The stereotypy of recurrent events is an essential feature of seizures. A witness account is helpful but not infallible and limb jerking secondary to transient hypoxia may be misinterpreted as tonic-clonic seizure activity. Questionnaires such as that developed by Sheldon et al. ${ }^{1}$ can facilitate differentiation of seizures from syncope.
Physical examination can be supportive if lateralizing signs are identified and should include visual field assessment for identification of structural lesions within the optical pathway. ${ }^{2}$ General examination may also yield findings such as skin changes seen in tuberous sclerosis or neurofibromatosis. Further clues as to cardiac or syncopal causes include findings such as irregular pulse or postural hypotension. Our patient had a normal cardiorespiratory examination and an ECG was performed that was unremarkable, making these less likely.

In this case, the presence of difficult to describe aura, lateral tongue bite, and a prolonged postictal period favored an epilepsy diagnosis. The witnessed tonic phase and abnormal physical examination are also supportive of a structural lesion in the left hemisphere and thus in this case a clinical diagnosis of probable focal epilepsy was made. The American Epilepsy Society guidelines ${ }^{3}$ recommend EEG and brain imaging for adults with a suspected unprovoked seizure. EEG and brain MRI were performed (figure, $\mathrm{A}$ and $\mathrm{B}$ ) to support the clinical diagnosis and classification of the seizures, to enable prognostication, and

Figure Illustrative section of EEG displayed on a double banana montage and axial T2 MRI sequences
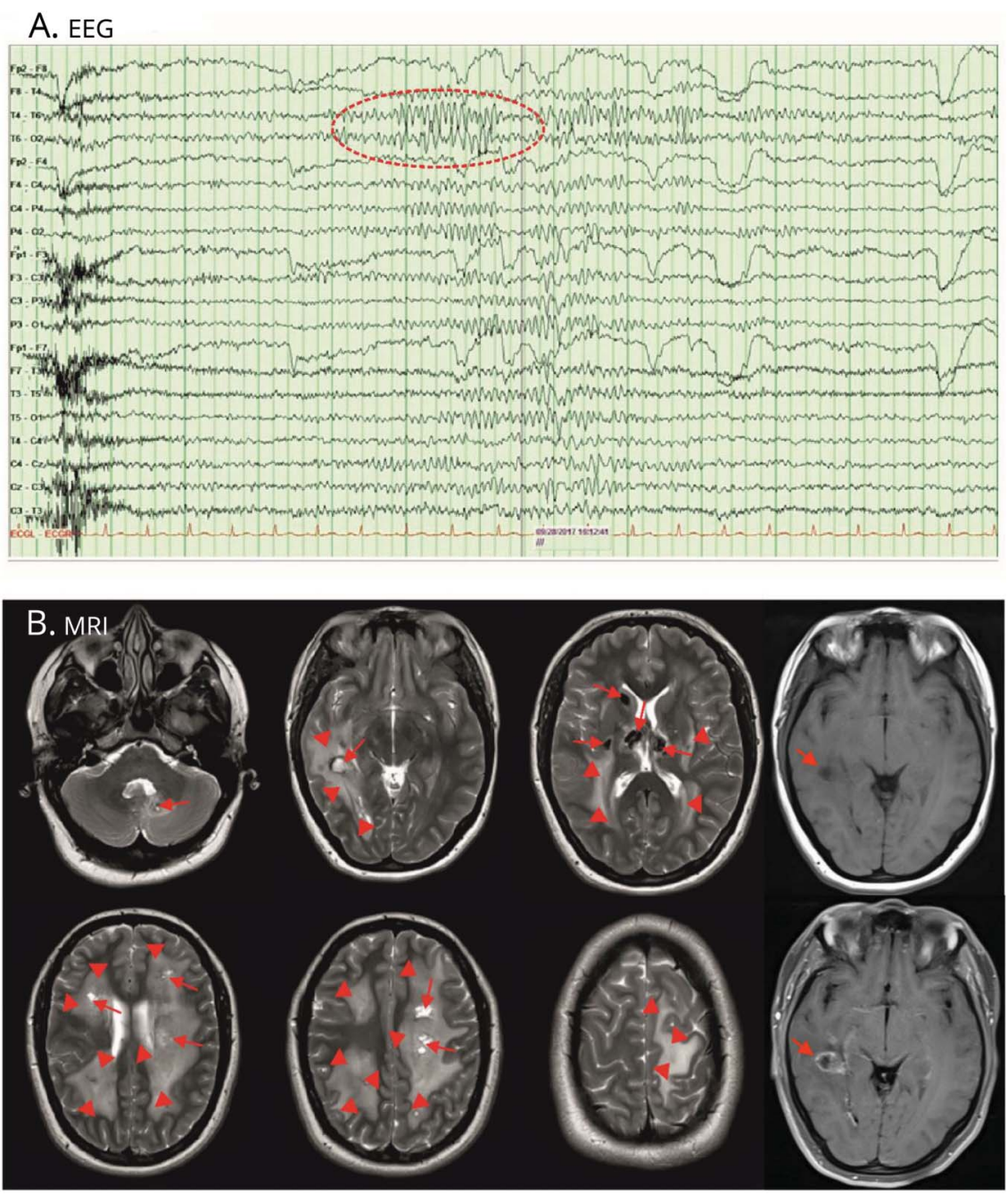

(A) Double banana montage. Thick vertical lines demarcate 1 second of data. The highlighted area shows a high-amplitude, sharpened alpha rhythm over the right posterior temporal/occipital region. (B) Axial T2 MRI scan shows multifocal lesions with calcification (marked by arrows) indicative of a chronic process. The images on the far right are T1-weighted pre and post (upper right and lower right, respectively) gadolinium contrast administration and identify a ring-enhancing lesion. There are diffuse T2 changes (marked with arrowheads) within both the cerebral and cerebellar hemispheres. Perfusion imaging (not illustrated) showed increased perfusion within the enhancing lesions and diffusion-weighted imaging (not illustrated) showed no evidence of restricted diffusion. 
to investigate for abnormal electrical activity supportive of seizures and structural brain lesions, respectively.

The EEG demonstrated a well-formed background with a sustained and responsive $10-11 \mathrm{~Hz}$ alpha rhythm but with marked asymmetry; at times the alpha rhythm recorded over the right posterior temporal/occipital region appeared highamplitude and sharper in outline (figure, A). No interictal electrographic seizure activity was identified and the lead I ECG recorded simultaneously showed sinus rhythm.
MRI brain showed multifocal lesions with calcification, indicative of a chronic process, and gadolinium enhancement and diffuse T2 white matter changes within both the cerebral and cerebellar hemispheres (figure, B).

\section{Questions for consideration:}

1. What is the differential diagnosis of the etiology of the seizures based on the additional results?

2. What further testing should be arranged based on these MRI findings?

GO TO SECTION 3 


\section{Section 3}

The most likely diagnosis for the imaging changes, including ring enhancement, at this point is an atypical cerebral infection: the primary radiologic diagnosis, in the absence of systemic disease, was neurocysticercosis. The presence of gadolinium ring enhancement suggests an active process. It was important to promptly establish evidence for neurocysticercosis because of treatment implications.

Neurocysticercosis is a common cause of acquired epilepsy worldwide. ${ }^{4}$ Investigations should include routine blood tests, cranial imaging, ophthalmologic review, plain X-rays of muscles to screen for peripheral cysts, and stool examination for intestinal taeniasis. CSF may be tested using ELISA. Medical management is both symptomatic (e.g., antiepileptic agents for seizures) and specifically directed against the parasite (for example, albendazole) depending on the clinical state. ${ }^{5}$ Surgical intervention may be required in instances of hydrocephalus or intractable seizures with calcified cysts. CT has a role in identifying cysts with variable degrees of calcification.

Imaging features of neurocysticercosis depend on the stage of the disease. At the larval stage, the scolices may produce small $(5-20 \mathrm{~mm})$ lesions with little mass effect and no edema. Later, the cysts are larger, and the scolex may be visible within the cyst. Parenchymal cysts are described as vesicular, colloidal-vesicular, granular-nodular, and nodular-calcified as neurocysticercosis progresses. At the later, calcified stage of the disease, the scolices are usually no longer visible. ${ }^{6}$ The use of MRI modalities may aid diagnosis, with fluid-attenuated inversion recovery (FLAIR) being more sensitive to intraventricular cysts and susceptibility-weighted imaging better for calcified lesions. $^{6}$

We identified no risk factors for neurocysticercosis or atypical infection. Routine blood tests showed a raised white cell count (12.4) and C-reactive protein less than 5. Further inquiries revealed no history of foreign travel or other clear source of exposure to taenia parasites. The patient had no contact with tuberculosis, and previously had the Bacillus Calmette-Guerin vaccine. She had chicken pox as a child and had not subsequently had shingles. A viral screen for cytomegalovirus, Epstein-Barr virus, HIV, hepatitis C, and hepatitis B was negative.

CSF sampling showed no white cells, protein and glucose counts within normal limits, and negative cysticercosis ELISA. Fecal samples showed no ova, cysts, or parasites. CT thorax, abdomen, and pelvis and X-ray imaging of the thigh showed no peripheral cysts or calcifications.

\section{Question for consideration:}

1. Based on the negative test results, how would you expand the differential?

\section{GO TO SECTION 4}




\section{Section 4}

The differential diagnosis for cysts with calcification includes cryptococcus, echinococcus, toxoplasma, and tuberculosis. Multiple abscesses would be unlikely with calcification, no fever, and no clear source of infection. Tuberculosis was also believed to be unlikely with no other area of abnormality and normal imaging elsewhere. Endemic fungi seldom calcify in the active phase and the patient had no history of travel to endemic areas. No positive confirmatory findings were made, leaving us without a history of exposure to cysticercosis and no significant supporting diagnostic features of neurocysticercosis (see section 3). Excision biopsy may be considered for cases of diagnostic uncertainty. In this instance, the case was discussed with colleagues (H.K. and S.T.) from an international center where neurocysticercosis is commonly encountered and with greater expertise in identifying neurocysticercosis. The lesions and extensive white matter changes were believed to be atypical for neurocysticercosis and there were no visible scolices.

Once intracerebral infection had been excluded, the differential diagnosis of leukoencephalopathy with calcification, which includes conditions such as Aicardi-Goutières syndrome and adult-onset leukoencephalopathy with axonal spheroids and pigmented glia, became the focus of investigation. Leukoencephalopathy with calcification and cysts (LCC) was deemed the top differential of these because of slow progression and juxtaposition between widespread radiologic features and modest clinical signs.

Genetic testing performed at the University of Manchester, UK, identified sequence variants in the SNORD118 gene by direct sequencing. The patient was found to be heterozygous for the n.72A $>\mathrm{G}$ sequence variant and the $\mathrm{n}^{*} 9 \mathrm{C}>\mathrm{T}$ sequence variant. Both variants are associated with $\mathrm{LCC}^{7}$ and their presence was confirmed in the National Health Service laboratory. Genetic counseling was provided. In 2016, the genetic basis of LCC was identified, molecularly differentiating this disease from Coats plus due to biallelic mutations in components of CST, a key structural protein complex. LCC and Coats plus demonstrate a remarkably similar neuroradiologic picture, the clinical difference being the presence of non-neurologic features in Coats plus.

Our patient's seizure control improved and she remains on a single antiepileptic drug (AED). One year later, her seizures are rare and her mood is much improved.

\section{Discussion}

This case exemplifies how a rare condition may present with a familiar clinical picture; in this case, the patient's initial presentation was not unusual in terms of recurrent collapse, with at least one convincingly described seizure. Semiology suggested a focal epilepsy and asymmetrical examination findings in conjunction with her EEG strongly suggested a structural abnormality.

Abnormalities in EEG or cranial imaging warrant further investigation and suggest an increased likelihood of seizure recurrence, and therefore the utility of AEDs. The American Academy of Neurology recommends that patients presenting with a first unprovoked seizure who have a subsequent seizure should have AED treatment offered to them because the risk of more seizures is high: $57 \%$ by 1 year and $73 \%$ by 4 years. ${ }^{7}$

LCC is a rare autosomal recessive disorder characterized by variable neurologic decline with spasticity, seizures, and a movement disorder. ${ }^{8}$ It is a cerebral microangiopathy related to, but distinct from, Coats plus. The largest series to date ${ }^{9}$ shows the age at presentation varies from under 6 months to 54 years, with symptom onset at school age being most common. A total of 14 of 40 patients first presented with seizures. The demonstrated prognosis was variable, with 35 of 40 patients still living and the oldest being aged 54 years at time of publication.

A recent case study of an 18-year-old patient treated for 1 year with bevacizumab, a vascular endothelial growth factor inhibitor, showed improvement in bradykinesia and range of movement and cessation of deterioration of speech, gait, and dystonia. ${ }^{10}$ This correlated with a reduction in cyst load on MRI and reduced FLAIR-demonstrated white matter involvement.

\section{Study funding}

No target funding reported.

\section{Disclosure}

J. Wildman, M.R. Baker, D.A. Price, S. Tiwari, H. Kumar, G.I. Rice, and Y. Crow report no relevant disclosures. R.H. Thomas has received honoraria from Eisai, GW Pharma, Sanofi, UCB Pharma, and Zogenix and meeting support from Bial, LivaNova, and Novartis. Go to Neurology.org/ $\mathrm{N}$ for full disclosures.

Appendix Authors

\begin{tabular}{lll}
\hline Name & Location & Contribution \\
\hline $\begin{array}{l}\text { Jack } \\
\text { Wildman, } \\
\text { MBBS }\end{array}$ & $\begin{array}{l}\text { Royal Victoria Infirmary, } \\
\text { Newcastle-Upon-Tyne, UK }\end{array}$ & $\begin{array}{l}\text { Writing of the } \\
\text { manuscript }\end{array}$ \\
\hline $\begin{array}{l}\text { Mark R. } \\
\text { Baker, PhD, } \\
\text { FRCP }\end{array}$ & $\begin{array}{l}\text { Royal Victoria Infirmary, } \\
\text { Newcastle-Upon-Tyne; Institute of } \\
\text { Neuroscience, Newcastle }\end{array}$ & $\begin{array}{l}\text { Clinical insight, } \\
\text { revision of text }\end{array}$ \\
\hline $\begin{array}{l}\text { D. Ashley } \\
\text { Price, MD, } \\
\text { FRCP }\end{array}$ & $\begin{array}{l}\text { Royal Victoria Infirmary, } \\
\text { Newcastle-Upon-Tyne, UK }\end{array}$ & \\
\hline $\begin{array}{l}\text { Sarbesh } \\
\text { Tiwari, MD }\end{array}$ & $\begin{array}{l}\text { Institute of Neurosciences Kolkata, } \\
\text { India }\end{array}$ & Clinical insight \\
\hline $\begin{array}{l}\text { Hrishikesh } \\
\text { Kumar, MD }\end{array}$ & $\begin{array}{l}\text { Institute of Neurosciences Kolkata, insight } \\
\text { India }\end{array}$ & Clinical insight \\
\hline
\end{tabular}




\begin{tabular}{lll} 
Appendix & (continued) & \\
\hline Name & Location & Contribution \\
\hline Gillian I. Rice & $\begin{array}{l}\text { Faculty of Biology, Medicine and } \\
\text { Health, University of Manchester, } \\
\text { UK }\end{array}$ & Genetic analysis \\
\hline $\begin{array}{l}\text { Yanick } \\
\text { Crow, PhD, }\end{array}$ & $\begin{array}{l}\text { MRC Institute of Genetics and } \\
\text { MRCP }\end{array}$ & $\begin{array}{l}\text { Edinburgh, UK; Institut Imagine, } \\
\text { Descartes University, Paris, France }\end{array}$ \\
\hline $\begin{array}{l}\text { Rhys H. } \\
\text { Thomas, } \\
\text { PhD, FRCP }\end{array}$ & $\begin{array}{l}\text { Royal Victoria Infirmary, } \\
\text { Newcastle-Upon-Tyne; Institute of } \\
\text { Neuroscience, Newcastle }\end{array}$ & $\begin{array}{l}\text { Lead clinician, } \\
\text { revision of text, } \\
\text { guarantor }\end{array}$ \\
\hline
\end{tabular}

\section{References}

1. Sheldon R, Rose S, Ritchie D, et al. Historical criteria that distinguish syncope from seizures. J Am Coll Cardiol 2002;40:142-148.
2. Smith PE. The bare essentials: epilepsy. Pract Neurol 2008;8:195-202.

3. Krumholz A, Wiebe S, Gronseth GS, et al. Evidence-based guideline: management of an unprovoked first seizure in adults: report of the Guideline Development Subcommittee of the American Academy of Neurology and the American Epilepsy Society. Neurology 2015;84:1705-1713.

4. Newton CR, Garcia HH. Epilepsy in poor regions of the world. Lancet 2012;380: 1193-1201.

5. White AC Jr, Coyle CM, Rajshekhar V, et al. Diagnosis and treatment of neurocysticercosis: 2017 Clinical Practice Guidelines by the Infectious Diseases Society of America (IDSA) and the American Society of Tropical Medicine and Hygiene (ASTMH). Am J Trop Med Hyg 2018;98:945-966.

6. Garcia HH, Nash TE, Del Brutto OH. Clinical Symptoms, diagnosis, and treatment of neurocysticercosis. Lancet Neurol 2014;13:1202-1215.

7. Hauser WA, Rich SS, Lee JR, Annegers JF, Anderson VE. Risk of recurrent seizures after two unprovoked seizures. N Engl J Med 1998;338:429-434.

8. Jenkinson EM, Rodero MP, Kasher PR, et al. Mutations in SNORD118 cause the cerebral microangiopathy leukoencephalopathy with calcifications and cysts. Nat Genet 2016;48:1185-1192.

9. Labrune P, Lacroix C, Goutieres F, et al. Extensive brain calcifications, leukodystrophy, and formation of parenchymal cysts: a new progressive disorder due to diffuse cerebral microangiopathy. Neurology 1996;46:1297-1301.

10. Fay AJ, King AA, Shimony JS, Crow YJ, Brunstrom-Hernandez JE. Treatment of leukoencephalopathy with calcifications and cysts with bevacizumab. Pediatr Neurol 2017;71:56-59.

\section{New, Free Mobile Learning App Offers Complimentary Self-assessment CME}

The American Academy of Neurology is pleased to offer a new, mobile educational resource-free to AAN members! The Neurology Question of the Day mobile app offers a quick, convenient, and fun way to assess your knowledge and fulfill selfassessment CME requirements. Get started at AAN.com/QODapp.

\section{Visit the Neurology ${ }^{\circledR}$ Resident \& Fellow Website}

Click on Residents \& Fellows tab at Neurology.org.

Now offering:

- Neurology ${ }^{\circledR}$ Resident \& Fellow Editorial team information

- "Search by subcategory" option

- E-pearl of the Week

- RSS Feeds

- Direct links to Continuum ${ }^{\circledR}$, Career Planning, and AAN Resident \& Fellow pages

- Recently published Resident \& Fellow articles

- Podcast descriptions

- Blogs by Editors and Resident \& Fellow team members

f Find Neurology ${ }^{\circledR}$ Residents \& Fellows Section on Facebook: facebook.com/AANResidentsAndFellows

Follow Neurology ${ }^{\circledR}$ on Twitter: @GreenJournal \#NeurologyRF

(0) Find Neurology ${ }^{\circledR}$ Residents \& Fellows Section on Instagram: @aanbrain \#NeurologyRF 


\section{Neurology}

\section{Clinical Reasoning: A 25-year-old woman with recurrent episodes of collapse and loss of consciousness}

Jack Wildman, Mark R. Baker, D. Ashley Price, et al.

Neurology 2020;94;994-999 Published Online before print May 1, 2020

DOI 10.1212/WNL.0000000000009533

This information is current as of May 1, 2020

\section{Updated Information \&} Services

\section{References}

Subspecialty Collections

Permissions \& Licensing

Reprints including high resolution figures, can be found at: http://n.neurology.org/content/94/22/994.full

This article cites 10 articles, 4 of which you can access for free at: http://n.neurology.org/content/94/22/994.full\#ref-list-1

This article, along with others on similar topics, appears in the following collection(s):

All Epilepsy/Seizures

http://n.neurology.org/cgi/collection/all_epilepsy_seizures

All Genetics

http://n.neurology.org/cgi/collection/all_genetics

Clinical neurology examination

http://n.neurology.org/cgi/collection/clinical_neurology_examination

Clinical neurology history

http://n.neurology.org/cgi/collection/clinical_neurology_history

Information about reproducing this article in parts (figures,tables) or in its entirety can be found online at:

http://www.neurology.org/about/about_the_journal\#permissions

Information about ordering reprints can be found online:

http://n.neurology.org/subscribers/advertise

Neurology ${ }^{\circledR}$ is the official journal of the American Academy of Neurology. Published continuously since 1951, it is now a weekly with 48 issues per year. Copyright (C 2020 American Academy of Neurology. All rights reserved. Print ISSN: 0028-3878. Online ISSN: 1526-632X.

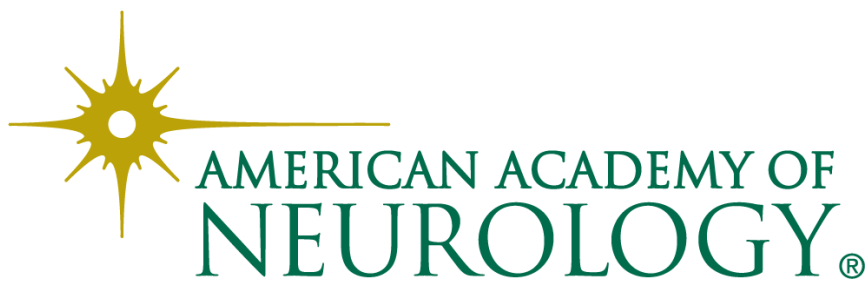

